\title{
Prospective Prices \\ for Food and Farm Products in 1967
}

\section{Food Prices}

Cons 1ONSUMER FOOD PRICES rose about 5 per cent and accounted for about one-third of the 3.7 per cent increase in the consumer price index during the year ending in October 1966. Food prices in 1967 are likely to continue to rise, but their upward thrust on consumer prices will be less than in 1966, according to the United States Department of Agriculture.

The estimated slower rate of increase in food prices in 1967 is based on projections of stable farm commodity prices accompanied by increases in food processing and marketing costs at about the same rate as in most recent years. Farm commodity costs account for about two-fifths of total food costs, and processing and marketing costs, for three-fifths.

The large increase in food prices in 1966 reflected both a sizable increase in farm commodity prices and higher costs of processing and marketing. Farm prices rose somewhat in 1965 and increased at a faster rate in 1966. During the first eleven months of 1966 such prices averaged 7.9 per cent above levels for the same months a year earlier (Chart 1 ).

chort 1

Prices of Food and Farm Products

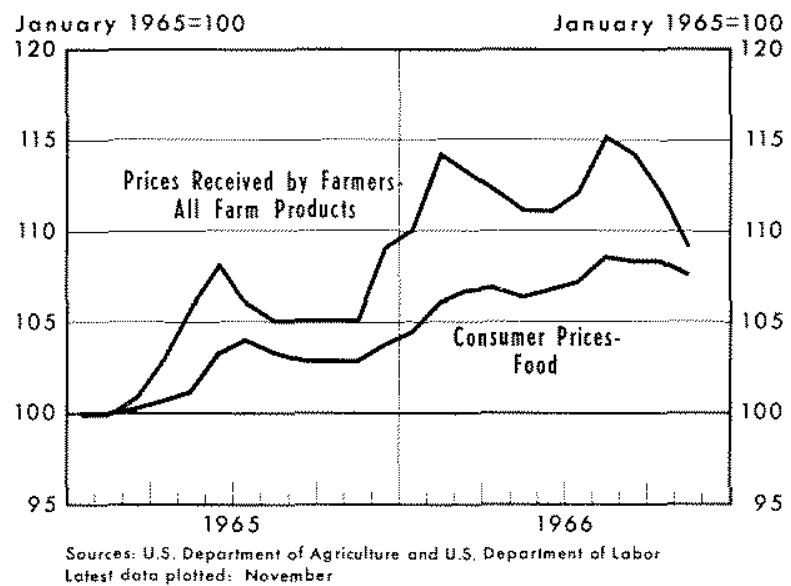

NOTE. This article is based on information presented by the staff of the United States Department of Agriculture at the 44th Annual National Agrieultural Outlook Conference in Washington, D. C., November I4-17, 1966.
Since the late 1950's food processing and distributing costs have gone up at a faster rate than farm commodity prices. During this period food prices rose at a rate of 1.7 per cent, while prices received by farmers increased at a rate of 1.2 per cent (Chart 2). Farm commodity prices actually remained almost stable from the late 1950 's to 1964 . The increase in food processing and marketing costs has been the major factor in rising food prices.

$$
\text { chort? }
$$

Prices of Food and Farm Products

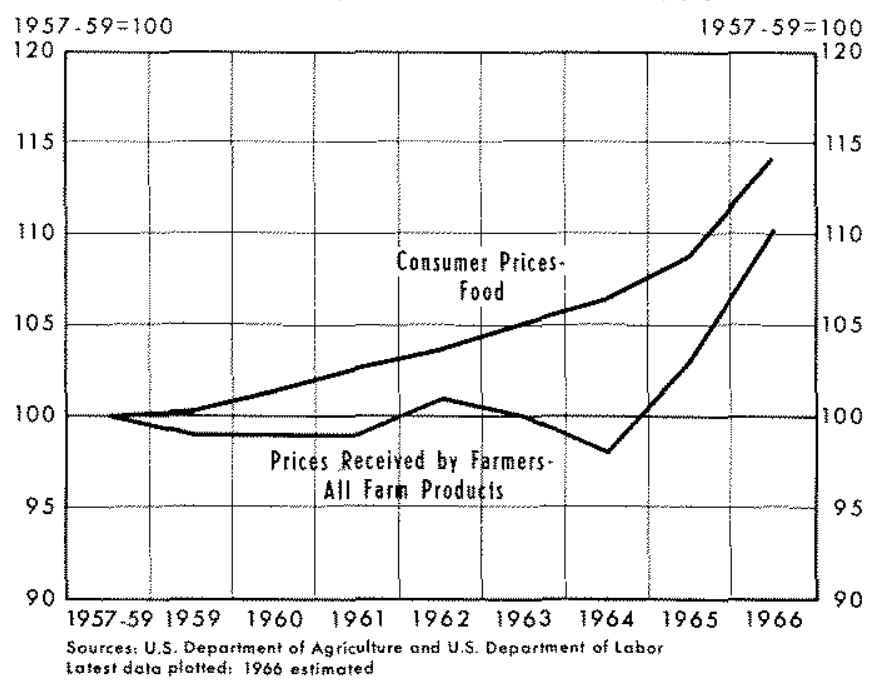

The upward trend of food prices over the past several years reflects changes in the amount of food processing demanded by consumers and rising costs of processing and distribution which are not offset by greater efficiencies. It is estimated that 1,500 new grocery items, most of which represent additional processing of farm products, are placed on supermarket shelves each year. Approximately 500 of these items survive the first year; thus each two years about 1,000 new items are added. ${ }^{1}$ This large array of new food products is an indication of the additional processing services that contribute to rising food costs and for which consumers are willing to pay.

\footnotetext{
"USDA, "Agricultural Markets in Change," talk by Kenneth Ogren at the 44th Anmual National Agricultural Outlook Conference, Washington, D. C, November 14, 1966.
} 


\section{Farm Commodity Prices}

The relatively small change in average farm commodity prices predicted for 1967 is based on an in. crease in farm output with an offsetting increase in demand. A larger farm ontput and stable prices point to an increase in gross receipts from farm marketings in 1967. However, since Government payments to farmers are likely to be smaller, little change is $\mathrm{ex}$ pected in gross farm income, which totaled about $\$ 49$ billion in 1966 . Production expenses are likely to continue upward, resulting in a decline in net farm income from the near-record level of $\$ 16.1$ billion in 1966. Net income is expected, however, to be well above the $\$ 14.2$ billion of 1965 . Net income per farm may decline slightly from the 1966 record level but should still be the second highest on record and about 60 per cent above the 1960 figure.

Supplies of livestock products will likely be about the same in 1967 as the near-record production of 1966. Crop supplies in the 1966-67 marketing year are down from year-earlier levels as a result of both smaller crops in 1966 and a reduction in carry-over stocks from prior years. Supplies of wheat are down about 300 million bushels, to 1.8 billion bushels. Feed grains are down 15 million tons, to 201 million tons. Cotton and tobacco supplies are also somewhat smaller. Rice and soybean supplies are greater (Table I).

Upward pressure on prices of most crops which would ensue from the more stringent supply situation is limited to some extent by the carry-over stocks held by the Government. Such stocks can be released to augment supplies in commercial channels. Also contributing to the prospects for relatively stable prices for crops, despite reduced supplies in the early part of the calendar year, are the sizable increases in prospect for 1967 production. The revised Covernment program for 1967 crops is expected to release a large amount of land to crop production purposes from the Acreage Diversion Program. In total, 25 to 30 million of the 60 million diverted acres could be used, but only about 15 million acres are expected to be returned to production.

Demand for farm products is expected to rise further in 1967. A larger population, more jobs, and pros. pects for a further increase in wage rates will in. crease consumer buying power and the domestic demand for farm products.

Reflecting greater foreign demand, exports of farm products are expected to increase about 6 per cent in $1966-67$, to $\$ 7$ billion from the $\$ 6.7$ billion total of 1965-66. Exports were up $\$ 0.5$ billion in 1965-66 or about 10 per cent from a year earlier. Increases are likely for cotton, tobacco, soybeans, and rice. Most of the export increase is expected in commercial sales for dollars. Exports under Governmentfinanced programs, largely donations, will probably continue near the $\$ 1.6$ billion total of the $1965-66$ fiscal year.

Table 1

SUPPLIES OF MAJOR CROPS:

$\frac{\text { Feed Groins }}{\text { (Million tons) }}$

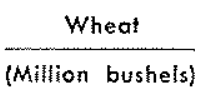

Carry-Over Stocks

from Previous Year

\begin{tabular}{l} 
1964-65 \\
$1965-66$ \\
$1966-67$ \\
Praduction \\
\hline $1964-65$ \\
$1965-66$ \\
$1966-67$ \\
Tota! Supply \\
$1964-65$ \\
$1965-66$ \\
$1966-67$ \\
Totd! Use \\
\hline $1964-65$ \\
$1965-66$ \\
$1966-67^{2}$
\end{tabular}

$\frac{\text { Rice }}{\text { (Rough) }}$ (Million cwt)
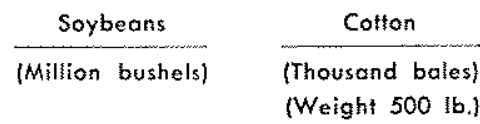

(Thousand bales)
(Weight $500 \mathrm{lb}$.)

$\begin{array}{rr}12,378 & 4,323 \\ 14,291 & 4,496 \\ 16,862 & 4,342 \\ & \\ 15,182 & 2,228 \\ 14,956 & 1,855 \\ 9,627 & 1,909 \\ & \\ 27,560 & 6,551 \\ 29,247 & 6,351 \\ 26,489 & 6,251 \\ & \\ 13,230 & 2,055 \\ 12,439 & 2,007 \\ 14,675 & 2,146\end{array}$

1 Marketing year beginning July 1 for wheat and tobacco, October 1 for most feed grans, August 1 for rice and cotton, and September 1 for soybeans. 2 Projected estimates.

Source: USDA. 
SELECTED U. S. CROP EXPORTS

\begin{tabular}{|c|c|c|c|c|c|c|c|c|}
\hline & \multicolumn{4}{|c|}{$\begin{array}{l}\text { Quantity } \\
\text { (Miltions) }\end{array}$} & \multicolumn{4}{|c|}{$\begin{array}{c}\text { Value } \\
\text { (Millions of dallars) }\end{array}$} \\
\hline & $1959-63$ & & & & $1959-63$ & & & \\
\hline & Average & 1964 & 1965 & $1966^{1}$ & Average & 1964 & 1965 & 19661 \\
\hline Feed grcins (pounds) & $28,266.8$ & $35,953.2$ & $46,868.0$ & $56,008,0$ & 634.0 & 853.3 & $1,133.6$ & $1,374.6$ \\
\hline Wheat (bushels) & 600.9 & 818.0 & $693 . ?$ & 929.5 & $1,049.5$ & $1,467.0$ & $1,139.3$ & $1,551.6$ \\
\hline Rice, milled (pounds) & $2,024.6$ & $2,929,0$ & 3.402 .7 & $2,913.5$ & 132.2 & 204.6 & 243.0 & 215.4 \\
\hline Soybeans (bushels] & 148.0 & 209.5 & 227.7 & 197.7 & 367.9 & 566.9 & 650.1 & 610.3 \\
\hline Colton (runnirg boles) & 5.2 & 5,2 & 3.8 & 2.9 & 680.9 & 681.7 & 486.2 & 353.6 \\
\hline \multicolumn{9}{|l|}{ Tobacco, unmonufaclured } \\
\hline (pounds) & 487.4 & 514,5 & 468.1 & 454.8 & 378.6 & 412.8 & 382.7 & 386.7 \\
\hline
\end{tabular}

1. Arnual rate, first nime months,

Sonter: USDA.

Increases in exports in recent years have been greatest for feed grains, wheat, rice, and soybeans (Table II). Exports of feed grains in calendar year 1966 were up about one-fourth from a year earlier and were more than double the 1959-63 average. World exports of feed grains have increased 16 per cent per year in the last five years. The United States accounted for more than half the total of such exports in 1965-66. Wheat and rice exports during the past two years have exceeded the $1957-59$ average by more than 50 per cent, and the increase in soybean exports has been only slightly less.

\section{Livestock and Livestock Products}

Prices of livestock and livestock products are expected to be about the same in 1967 as in 1966. Prices in 1966 were about 12 per cent higher than a year earlier primarily because of reduced supplies of pork, eggs, and milk. In the first quarter of the year livestock prices reached the highest level since 1952, and hog prices in January were the highest for any month since September 1948. Production increases for livestock products in late 1966 point to larger supplies and somewhat lower prices in early 1967.

Fed cattle marketings this winter are expected to run ahead of year-earlier levels, and hog slaughter is likely to exceed last year's levels by 10 to 12 per cent. Egg production may be 3 to 5 per cent larger, and potultry production is expected to be somewhat greater. Later in the year fed cattle slaughter may decline, resulting in somewhat less beef production for the entive year than in 1966. Increased hog slaughter and somewhat larger beef imports will partially offset the reduced beef and veal production; however, total red meat supplies for the year may be down about 3 per cent. Supplies of broilers and turkeys will be larger and should about offset the decline in red meat.
Prices for poultry and eggs are likely to average below year-earlier levels, at least during the first half of 1967. Increased broiler hatchings during late 1966 and a build-up in laying focks point to increased supplies during the first half of the year. Broiler production is expected to continue to rise at the 5 to 10 per cent rate of a year earlier. Most of the gain may occur, however, in the first part of the year, and the lower prices anticipated will tend to inhibit increases during the last half. Turkey production may not match the 11 per cent gain of a year earlier but should about equal the lower rate of the previous two years. Egg production may exceed 1966 output by 3 per cent. In late 1966 the number of potential layers on farms exceeded year-earlier numbers by 4 per cent, and the proportion of high-laying pullets was also greater. Larger-than-year-earlier output from this flock should continue at least through the summer months.

Farmers are assured higher prices in early 1967 than a year earlier for manufacturing grade milk by the current Government price support level of $\$ 4.00$ per cwt. Prices for the entire year are likely to average higher than year-earlier levels. Milk prices in 1966 averaged about 60 cents per cwt. more than in 1965 and close to the $\$ 4.88$ per cwt. record of 1948 .

Supplies of milk in 1967 are expected to rise somewhat from year-earlier levels. Production has been on the upswing since February 1966, when output was 6 per cent below year-earlier levels. By the end of 1966 output probably exceeded the year-earlier rate. Rising output, coupled with favorable prices, suggests a high level of milk output in 1967. Higher production is shielded to some extent from market forces by Government price support and will not be reflected in lower prices. Production gains will be reflected in larger Government removals of milk from the market through Commodity Credit Corporation purchases. Such purchases, however, will still be low relative to 1961-64 levels. 


\section{Crops}

Crop prices in 1967 are likely to average about the same as in 1966. Although total crop output in 1966 was down about 4 per cent from the year-earlier record and carry-over stocks were less, these supply reductions are not expected to influence prices greatly, Release of commodities from Govermment stocks is expected to provide supplies adequate to meet demand at current prices.

The somewhat reduced supplies of feed grain and continued strong demand are expected to result in somewhat higher feed grain prices during the early part of the 1966-67 marketing year. Prices, well above year-earlier levels near the close of 1966 , however, are not expected to increase as much during the spring and summer as during the past two years. The 1966 67 feed grain supply totals about 201 million tons, 7 per cent less than a year earlier. The 1966 crop totaled 158 million tons, and carry-over, 43 million (Table I). Utilization is expected to continue at the 1965-66 rate of 174 million tons. In this event, carry-over into the 1967-68 marketing year will decline to 25 to 30 million tons, or about 15 per cent of annual use. It is this change in the supply situation which has prompted the Administration to change the Feed Grain Program for 1967 to encourage larger production. This increase will tend to weaken prices during the autumn months. The program also provides for an increase from $\$ 1.30$ to $\$ 1,35$ per bushel in the price support for corn, with comparable increases in the support rates for other feed grains.

Based on current supply and demand factors, the average price for wheat is likely to be 10 to 20 per cent above last year's $\$ 1.34$ per bushel. Total supplies of 1,832 million bushels (production of 1,296 million bushels plus carry-over of 536 million bushels) are down about 15 per cent from year-earlier levels. Utilization, however, is expected to decline sharply from the record 1965-66 rate that resulted in a reduction in carry-over stocks of almost 50 per cent. Domestic use of wheat may decline about 10 per cent from the 742 million bushels in 1965-66, primarily because of a reduction in use of wheat for feeding livestock. Exports, about two thirds of which are Government financed, are expected to be down 100 to 125 million bushels from the record 867 million bushels exported in 1965-66.

The price of wheat will also be affected by expanded program plans for 1967. Wheat allotments were increased 8.9 million acres last August, bringing the total allotment to 68.2 million acres. The total of price supports and marketing certificate payments is also likely to be somewhat higher. The price support rate will be $\$ 1.25$ per bushel, the same as a year earlier, while the marketing certificate payments (parity price less $\$ 1.25$ per bushel) on 520 million bushels will likely be higher.

Rice prices to farmers in the marketing year 196667 are likely to average about the same as the $\$ 4.89$ per cwt. received a year earlier. Supplies, the 1966 crop plus the carry-over, total about 93 million cwt., 10 per cent more than a year earlier. Utilization is expected to rise by about the same amount as the increase in supplies. Rice for domestic food, seed, and industrial uses may climb about 1.5 million cwt. to a total of 32 million cwt. Exports in 1965-66 totaled 43.3 million ewt. (27.1 million cwt. for dollars) and some further increase, especially for dollars, is likely in 1966-67. Carry-over stocks at the end of the year may increase slightly from the 7 to 8 million cwt. of recent years.

Prices of soybeans moved up rapidly from $\$ 2.38$ per bushel during the 1965 harvesting season to $\$ 3.63$ per bushel in August 1966 and held part of this gain during the 1966 harvesting season, with prices averaging about $\$ 2.78$ per bushel, 20 per cent above year-earlier levels. Although prices were substantially higher during the 1966 harvesting season than a year earlier, for the entire year they may average only about 10 per cent higher, as only moderate increases from the seasonal trough are expected. The Government sup port price for soybeans is $\$ 2.50,25$ cents above the rate of a year earlier. However, the market price, as in most recent years, is likely to be above the support price. Supplies of soybeans of about 963 million bushels, 10 per cent above year-earlier levels, are about in line with the long-run growth trend. Production has tripled since 1950, and carry-over stocks have never been excessive, exceeding 10 per cent of total supplies in only two years. Domestic utilization is forecast at 641 million bushels, and exports, at 275 million, both about 19 per cent above year-earlier levels. Carry-over stocks may thus be somewhat in excess of the 36 million bushels last year.

Cotton prices are determined largely by the level of Government price supports. The loan rate on the 1966 crop was 21.00 cents per pound, and an additional 9.42 cents per pound was paid on the normal production of domestic allotment acres to farmers who cooperated in the Government Cotton Program. Under this system the volume of stocks rather than price reflects changing supply and demand conditions. Stocks totaling 16.9 million bales at the beginning of the 1966-67 marketing season are well above annual use in recent years. Production of only 9.6 million bales, 
however, was the smallest crop since 1945. This crop reffected the smallest planted acreage, 9.8 million acres, in nearly 100 years and a slight decline in average yield. Carry-over into the current season totaled 16.9 million bales, well above total annual domestic and export use. On the demand side, domestic mill consumption of cotton is expected to total 9.6 million bales in 1966-67, up about 5 per cent from a year earlier. Exports may total 5 million bales, which would represent a sharp recovery from last year's 2.9 million level. If these rates of use are achieved, carry-over stocks on August 1,1967 will be reduced 5 million bales from year-earlier levels to about 11.9 million bales. A 1967 cotton acreage allotment of 16 million acres, the same as last year, has been announced by the United States Department of Agriculture. This is the same allotment as for the past four years. The Government loan rate has been lowered from 21.00 to 20.25 cents per pound, and production payments on domestic allotment acres have been raised from 9.42 to 11.53 cents per pound. The diversion payment was also slightly increased.

The price of tobacco, like the price of cotton, is determined largely by the Government Price Support Program. Price supports were up 2 per cent for the 1966 tobacco crop, and support levels for the 1967 crop are likely to be up another 2 per cent. Total tobacco supplies of 6,251 million pounds for the 1966-67 marketing year were slightly below levels of the past two years. Tobacco use (domestic plus exports), however, was down in the marketing year beginning July 1, 1965 from a year earlier. Use of flue-cured tobacco totaling 1,175 million pounds was the lowest since 1956, and use of burley tobacco totaling 601 million pounds was down from $616 \mathrm{mil}-$ lion pounds a year earlier but was above that of prior years. Domestic use of Alue-cured tobacco in 1966-67 is not expected to vary much from the reduced level of 1965-66. Exports, however, which account for about one-third of total use, may rise substantially as a result of the ban on Rhodesian tobacco by most major importing countries. Thus, fue-cured stocks, which totaled 2,439 million pounds on July 1, 1966, the third largest on record, are likely to decline by a sizable amount during the current marketing year. Burley tobacco supplies of 1,938 million pounds are about 4 per cent less than the comparatively high levels of the previous two years. Combined use for domestic and export purposes in 1967 will likely be somewhat above the 601 million pounds of last year and well above the relatively small 1966 crop of 538 million pounds. Stocks on October 1, 1967 will likely be down substantially from year-earlier levels. 